Article

\title{
Sustainable Digitalization of Cultural Heritage-Report on Initiatives and Projects in Brandenburg, Germany
}

\author{
Ulf Preuss \\ University of Applied Sciences Potsdam, 14469 Potsdam, Germany; ulf.preuss@fh-potsdam.de; \\ Tel.: +49-331-580-1530 \\ Academic Editor: Victor T. King \\ Received: 31 May 2016; Accepted: 16 August 2016; Published: 3 September 2016
}

\begin{abstract}
While digitalization opens up new possibilities for cultural heritage and tourism it also brings new challenges. Initiatives such as "Europeana", an internet portal for cultural heritage within the European Union, support institutions with the display of their collections. National initiatives complement these efforts. This report describes initiatives and projects for generating and sustaining digital cultural heritage resources in the German state of Brandenburg. With the cultural heritage distributed throughout the state and managed by hundreds of institutions, the task of digitalization is a common challenge for all of these institutions. Digitalization and digital sustainability is limited by shortcomings in areas of human resources, knowledge and IT infrastructure. In light of these limitations, the cultural heritage community addresses challenges with an interdisciplinary approach. It is based on a collaborative model with four levels: (1) a statewide strategy of an interdisciplinary task force; (2) cooperative projects; (3) cooperative IT infrastructure; and (4) an overall coordination. The priorities are: (1) creating and displaying digital content; (2) establishing best practices and workflows; (3) developing cooperative infrastructures for sustainment. Since 2012, several projects have been implemented based on that collaborative model. More than 50 participating institutions benefited from cooperative planning, managing, digitizing and digital presentation. With regard to the third priority, the task force's next step is finding solutions for digital preservation. Considering the lack of funding and resources in the cultural heritage sector, options for creating and sustaining digital resources are limited. Digital cultural heritage requires interdisciplinary thinking, cooperative initiatives, reliable IT infrastructures and additional funding.
\end{abstract}

Keywords: cultural heritage; digitalization; digital preservation; cooperation; funding

\section{Introduction}

Cultural heritage is a key locational factor for a country's image. Visitors like to travel to Germany because of its rich cultural heritage, both tangible and intangible [1]. Its representations, such as monuments, artifacts or oral traditions [2], are spread throughout all sixteen states of the Federal Republic of Germany. In 2014, about 50 million tourists traveled to Germany [3]. Brandenburg attracted more than 900,000 overnight stays out of 75.6 million nationwide [3]. The internet is the most important way to book a trip [3]. In Germany alone, about 60 million people use the internet, making it one of the main information sources [4]. Touristic sites need to be digitally accessible in order to be digitally searchable. Additional, digital cultural heritage is a source for scientific research. Initiatives like "Europeana", an internet portal for the promotion of cultural heritage within the European Union, support institutions with the display of their collections [5]. National initiatives complement these efforts. One of them is the "Deutsche Digitale Bibliothek" (DDB) [6], a portal for cultural heritage in Germany. This report describes initiatives and projects for creating and sustaining 
digital cultural heritage resources, with a focus on tangible forms of cultural heritage and institutions in Brandenburg, Germany.

In what follows, this paper first covers definitions of essential terms and general requirements of digitalization, before, second, comparing the current status of institutions with the necessary requirements for digitalization. This includes, third, discussing the sustainability of digital resources in light of restrictions in basic areas like budget, human resources and IT infrastructure. Then, fourth, this paper presents an interdisciplinary approach to address such institutional restrictions, informed by the aim for pragmatic solutions in order to create sustainable digital resources. Fifth, the interdisciplinary approach is reflected with regard to its usefulness outside the described scope. Finally, the interdependencies between cultural heritage, citizen participation and tourism are discussed.

\section{Digitalization and Digital Presentation of Cultural Heritage}

In the context of this report, digitalization is a general term for all necessary steps to create and sustain digital resources. Therefore, it is much more than the mere act of digitizing something.

\subsection{What Does Digitizing Mean?}

Technically, to digitize means to transform non-digital objects (e.g., books or pictures) into a digital form [7]. Digital means to transform any kind of data into numbers ( 0 and 1 for binary systems) [7]. All digital data is thus coded information that requires decoding to become a meaningful resource. This process is based on a combination of computer hard- and software and electricity. For example, several components are necessary for typing a text into a computer and therefore digitizing it:

(1) Mechanical typing with a keyboard

(2) Creating an electric impulse which is transformed into a combination of 0 and 1

(3) Interpretation into a sign for a letter

(4) Being processed by software into a font and integrated into a file

(5) Translation into graphical interpretation to put on display

Therefore, digital data depends on the availability of said mandatory components in order to have any meaning.

\subsection{What Is Digital Presentation?}

From the perspective of internet users, digital presentation is the availability of information using search engines or individual websites. The information itself exists in very different formats, such as texts, images, audio or video files, as well as corresponding metadata in machine-readable exchange formats. Preferably, the necessary information should be accessible at any time. Moreover, it should be possible to generate exact and complete search results from the smallest amount of user input. What does this have to do with institutions such as archives, libraries or museums? The institutions' efforts to provide digital content to meet the ideals of digital presentation should not be underestimated.

\subsection{Components for Digitalization of Cultural Heritage}

The following conceptual components of cultural heritage are based on standards set by the Deutsche Forschungsgemeinschaft (DFG), a German national research funding organization. The standards derive from multiple projects to set up nationwide efficient research information systems and cover projects at libraries, archives and other scientific service and information centers in Germany [8,9]. The components are:

\section{(1) Content Specification}

Specification of content for digitalization means more than the selection of parts from a collection. It means answering questions such as: 
- What is the purpose of the digitalization?

- What kind of non-digital content needs to be transformed into digital content?

- What kind of digital use is anticipated?

- Can the original content be digitized without being damaged or destroyed?

- Do legal limitations apply to the digitalization or digital presentation, publication and use?

- Does the institution have all the necessary resources?

(2) Digital Cataloging

Digital cataloging refers to the creation of information about the digital content. This descriptive information is called metadata and includes, among other things, information about content, context and technical aspects. Different branches of cultural heritage use different metadata schemes and regulations, e.g., libraries use the framework Resource Description and Access (RDA) [10].

(3) Digitizing

Digitizing refers to the creation of digital representations. Thus, it does not indicate the transformation of the non-digital object itself, but the creation of digital forms to represent the original object (e.g., image, text or audio files).

(4) Digital Presentation

Digital presentation refers to the provision of access to digital content. Depending on the digital content, different tools for digital presentation are needed (e.g., a viewer for images or a multimedia player for audio and video files).

(5) Digital Backup

Digital backup is realized by securing the online database with adequate infrastructure and security mechanisms such as server capacity, bandwidth or backup.

(6) Digital Preservation

Digital preservation refers to the preservation of the significant properties of digital objects for the foreseeable future. It includes ongoing measures to ensure technical and organizational endurance.

\section{Challenges for the Digitalization of Cultural Heritage Institutions in Brandenburg}

In Brandenburg, more than 80 archives [11], 140 libraries [12] and 150 museums [13] hold the responsibility for preserving cultural heritage. These numbers mainly pertain to institutions with a fixed staff number. On top of that, there is a multitude of voluntarily operated institutions; the museum association of Brandenburg named a total number of 400 museums for the year 2009 in this context [14].

The monument list for Brandenburg contains more than 24,000 objects [15]. Bigger, coherent collections are placed in a relatively small number of institutions, such as the Brandenburg Main State Archive, the "dkw. Kunstmuseum Dieselkraftwerk Cottbus" gallery, the Brandenburg State Library or the foundation for the parks and palaces in Berlin and Brandenburg. This situation reflects the rural character of Brandenburg as well as the political reorganizations of the last two centuries that separated Brandenburg from the city of Berlin, leading to the dispersion of historical collections. One of these reorganizations took place in the wake of 1945, when the German Democratic Republic was formed in East Germany, entailing the creation of new governmental districts, the confiscation of property and the merger of collections. The last noteworthy political reorganization occurred with the reunification 
of Germany in 1990. It led to the political separation of Berlin and Brandenburg that brought with it the foundation of many new collections and institutions.

With the majority of collections distributed throughout the entire state and managed by hundreds of institutions, the digitalization of the cultural heritage is a task for every single institution. Especially smaller institutions do not feel equal to the task of providing the necessary expenses for a contemporary online presentation and the sustainment of digital resources. They lack the required human resources, knowledge and technical infrastructure. Institutions with only one or few staff members must concentrate on basic management tasks like the development of exhibitions and events, sustaining opening hours, public relations or cataloging the collection. In this setting, there is simply no room for building an additional knowledge base for digitalization. The limitations to the human resources are accompanied by limitations to the IT infrastructure. Most archives and museums use desktop PCs rather than server-based infrastructures. This can only be temporarily changed by additional resources from short term projects. As a result, there are no sustainable digital resources available on the level of the institutions. Thus, these institutions cannot comprehensively participate in the digital presentation of cultural heritage without additional funding and a different approach [16].

\section{An Interdisciplinary Approach to Digitalization}

In order to create and aggregate digital content for the "Europeana", the German government started the development of an interdisciplinary portal for cultural heritage in Germany in 2007, now known as the Deutsche Digitale Bibliothek (DDB). In autumn 2007, the Ministry of Science, Research and Culture in Brandenburg called for an interdisciplinary round table for the digitalization of cultural heritage. It consisted of representatives from archives, libraries, historic preservation, museums as well as research. Within two years and on behalf of the ministry, the round table developed a strategy paper which included an overview of ongoing and finished projects as well as existing resources. Furthermore, they put out a call for action for digitalization in the state of Brandenburg [16].

In light of the planned start of the DDB in 2012, an interdisciplinary task force called "Arbeitskreis Brandenburg.digital" (AKBD) was formed in the summer of 2011. The first item on its agenda was the general evaluation of the DDB in order to specify feasible ways for cultural institutions to participate. That evaluation took place in cooperation with the Faculty of Information Sciences at University of Applied Sciences Potsdam, and lead to a concept paper [17]. An essential source of information was the draft of the cooperation agreement by the DDB [18], which contained information about the allocation of responsibilities. For example, institutions that take part in the DDB are responsible for:

- Providing correct and authentic metadata and digital objects [18] (p. 4)

- Digitalization of the cultural heritage [18] (p. 3)

- Providing a persistent link to the data inside the data base of the institution [18] (p. 3)

- Digital preservation [18] (p. 6)

Considering the situation of Brandenburg's cultural institutions, the necessity of several components of digitalization and the responsibilities of participation in the DDB, the task force came to the conclusion that a cooperative approach is necessary. Furthermore, it advised implementing a coordination office for specialized support and transfer of knowledge. The same year the "Koordinierungsstelle Brandenburg-digital (KBD)" started its work at the University of Applied Sciences Potsdam [19].

In 2014, the task force developed a second concept paper [20], which contains a proposal for the implementation of actions to create and sustain digital cultural heritage resources, including the abovementioned mandatory digitalization components. Also, the task force developed guidelines for cooperation as well as project proposals for the participation of the cultural heritage institutions in the DDB (see Figure 1). These guidelines and projects refer to a cooperation network that consists of four levels. 


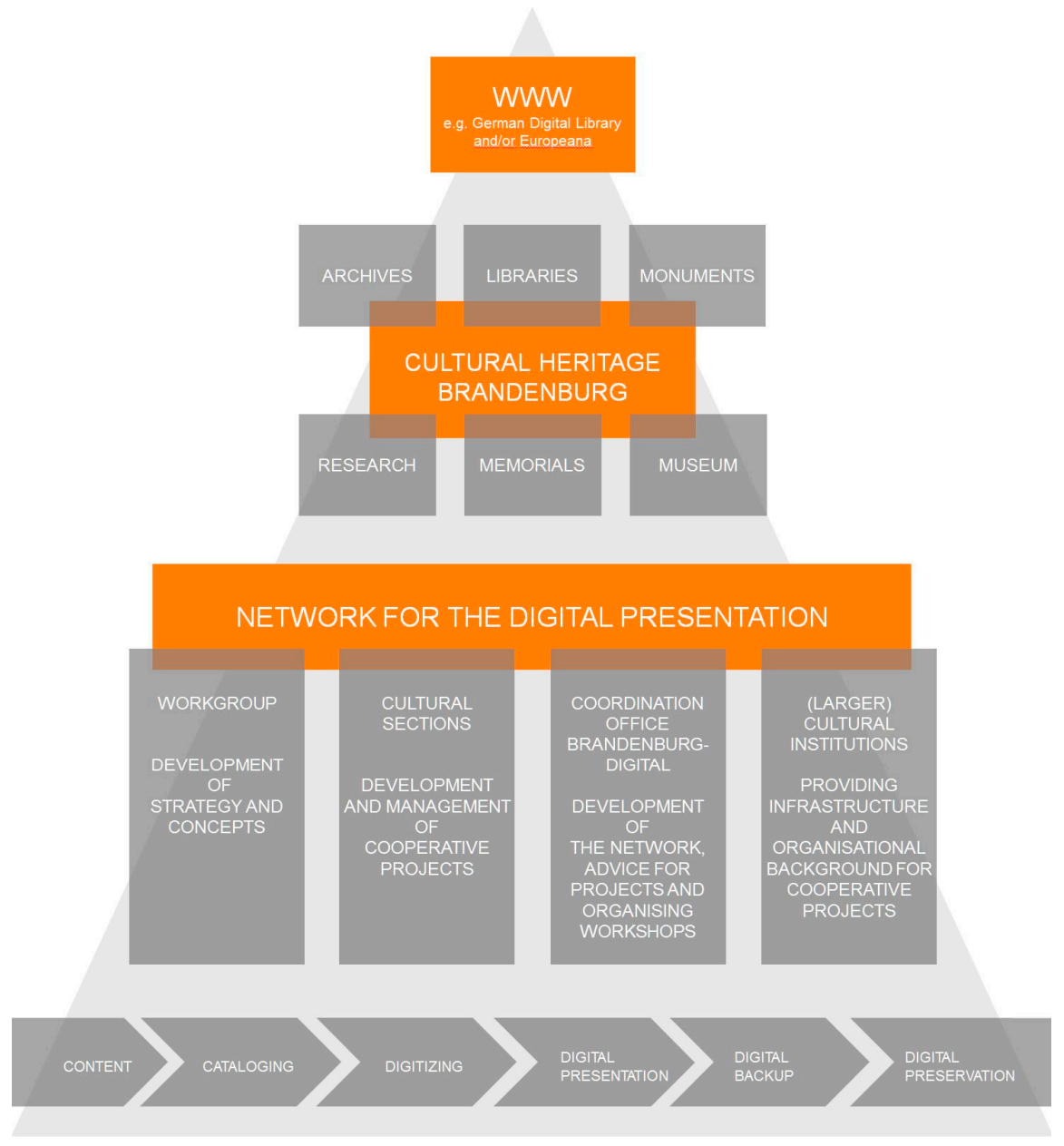

Figure 1. Components of the cooperative approach to the digitalization of cultural heritage in Brandenburg [21].

\subsection{Interdisciplinary Task Force}

The first level is the taskforce AKBD. It is responsible for developing strategies and concepts, supporting the Ministry of Science, Research and Culture's in the planning and setting of priorities. Currently, the following institutions participate in the task force [19]:

- Brandenburgische Gesellschaft für Kultur und Geschichte gGmbH/Haus der BrandenburgischPreußischen Geschichte [22]

- Brandenburgisches Landeshauptarchiv [23]

- Brandenburgisches Landesamt für Denkmalpflege und Archäologisches Landesmuseum [24]

- Brandenburgisches Literaturbüro [25]

- Fachhochschule Potsdam [26]

- Filmmuseum Potsdam [27]

- Deutsche Geologische Gesellschaft—Geologische Vereinigung e.V. [28]

- Deutsches GeoForschungsZentrum GFZ/Bibliothek des Wissenschaftspark Albert Einstein [29]

- Bibliothek der Filmuniversität Babelsberg Konrad Wolf [30]

- Landesfachstelle für Archive und öffentliche Bibliotheken [26]

- Museumsverband des Landes Brandenburg e.V. [31]

- Sorbisches Institut [32]

- Stadt- und Landesbibliothek Potsdam [33] 
- $\quad$ Stiftung Brandenburgische Gedenkstätten [34]

- $\quad$ Stiftung Preußische Schlösser und Gärten Berlin-Brandenburg [35]

- Universitätsbibliothek der Europa-Universität Viadrina Frankfurt (Oder) [36]

- Universitätsbibliothek der Universität Potsdam [37]

- Zentrum für Zeithistorische Forschung Potsdam [38]

The task force defines regulations for the implementation of a comprehensive digital presentation. It sets standards for project planning and organization.

\subsection{Project Planning and Management}

The focus of the second level is project planning and management, with a particular emphasis on interdisciplinary themes. Here, cooperative projects are centrally organized by a bigger institution or an association, such as the Museumsverband des Landes Brandenburg e.V. [31]. This includes the application for funding, administrative tasks and quality management. In doing so, smaller institutions are relieved of additional administrative tasks and can concentrate on their contribution to the project. This also simplifies the subsequent transfer of project outcomes into long-term structures, as it enables transfer of knowledge from one project to the next and contributes to the project outcomes in terms of quantity and quality.

\subsection{Cooperative IT Infrastructure}

The third level consists of bigger institutions within Brandenburg and transregional portals. They provide knowledge and infrastructure for cooperative projects. For example, the Potsdam University Library and the German Geological Society digitalized about 270 volumes of historical maps of Prussia (Geologische Spezialkarte von Preussen und den Thüringischen Staaten), see Figure 2.

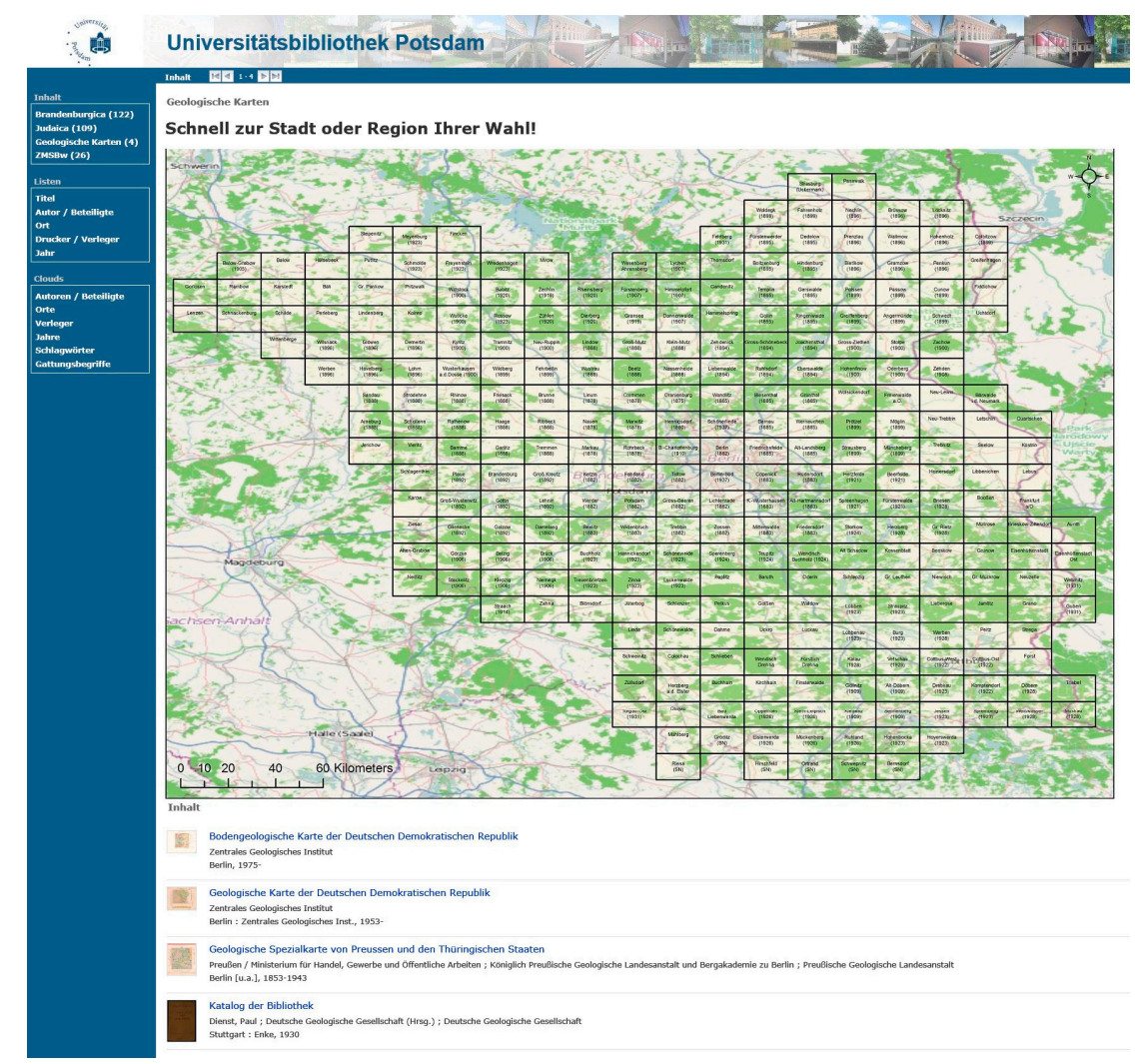

Figure 2. Collaborative digital presentation of historical geological maps [39]. 
Further emphasis is placed on the collaboration with nationwide or transregional platforms, such as "museum-digital" [40] and its Brandenburg section or the union catalog for collections of personal papers, manuscripts, and publishers' archives "Kalliope" [41]. Many institutions would have no basis for the digital presentation on a local or national scale without these platforms. They provide the necessary digital platform for participating in the DDB.

The use of cooperative platforms is also linked to a more homogeneous utilization of metadata and discipline-specific metadata schemes. Participating institutions apply the respective platform's standards, without the need to develop or maintain own metadata schemes. Since everyone is working with the same input masks, the effort of preparing data exports for a third-party platform, such as the DDB, is clearly minimized. The data records of the respective system only need to be transferred schematically into the target platform once, with a method called mapping. Mapping refers to the comparison between two metadata-schemes in order to find concordance. Fields with the same content and the same or a different label are crossed. Based on a list of cross concordance, the metadata scheme from the original system is transformed into the metadata scheme of the target system. For example, a field labeled "author" in system A is mapped to a field labeled "creator" in system B. All following data exports are based on this template.

\subsection{Network Coordination}

The coordination office (KBD), as the fourth level, is responsible for supporting and advising projects, from the development phase and the implementation to the transfer into sustainable structures. Part of the support is the communication of existing standards for digitalization projects, such as the digitalization guidelines by the DFG [9], the workflow model described in the Handbook for Digitalization of Printed Cultural Heritage [42] or legal orientation for digitalization projects [43]. In this context, cultural heritage institutions are paired with regional cooperation partners. The regional network is extended through cooperative connections to institutions from other federal states and the DDB.

Furthermore, the KBD organizes events and workshops on the multiple aspects of digitalization, thereby facilitating the transfer of knowledge and the exchange of experience. These services are complemented by a digitalization lab operated by the Faculty of Information Sciences at University of Applied Sciences Potsdam. Finally, outside of Brandenburg, the KBD cooperates with similar organizations, for example with the coordination office "Servicestelle Digitalisierung (digiS)" [44] in Berlin.

\subsection{Examples of Cooperative Projects}

Since 2012, the Ministry of Science, Research and Culture has funded twelve cooperative projects. More than 50 archives, libraries and museums participated in these projects, putting about 4000 objects on digital display. The projects covered a variety of topics:

- Brandenburg in motion pictures-documentary film as well as amateur film from 1950 to 1990 within the territory of the former German Democratic Republic (GDR) [45]

- Brandenburg in images-historical artwork of towns and locations [46]

- Glass plate photography_glass plates as photographic medium between 1850 and 1950 [47]

- Handwritten documents by the common people from everyday life from the 16 th to the 19th century [48]

- Heimatkalender-annually printed books on regional history collected by libraries [49]

- Collection about the history of southern Brandenburg in the 18th and 19th century [50]

\subsection{Data Exchange with DDB and "Europeana"}

When preparing a data export into the $\mathrm{DDB}$, institutions must transform their datasets into specific metadata schemes. In the case of museums, this is the LIDO format [51]. Most projects use the 
museum-digital portal, which is capable of mapping into LIDO. In 2015, the first institution signed the data exchange agreement with the DDB. The first data export took place in spring 2016, with digital content provided by the Potsdam Museum-Forum für Kunst und Geschichte [52]. This test case confirmed the technical feasibility of the workflow: (1) from the creation of digital content and (2) the use of a common web-based platform to (3) the transfer of datasets to a third-party platform. For example, the dataset of "Blick vom Brauhausberg-von Schloss Sanssouci bis zum Alten Rathaus" is now accessible through museum-digital (see Figure 3) as well as the DDB (see Figure 4). Another feature of museum-digital allows institutions to link metadata fields of "creator" and "location" to Wikipedia articles and authority files like the "Gemeinsame Normdatei (GND)" [53] or The Getty Thesaurus of Geographic Names Online [54]. This provides the foundation for linked open data [55]. The platform is search engine-optimized in order to make the content more accessible.

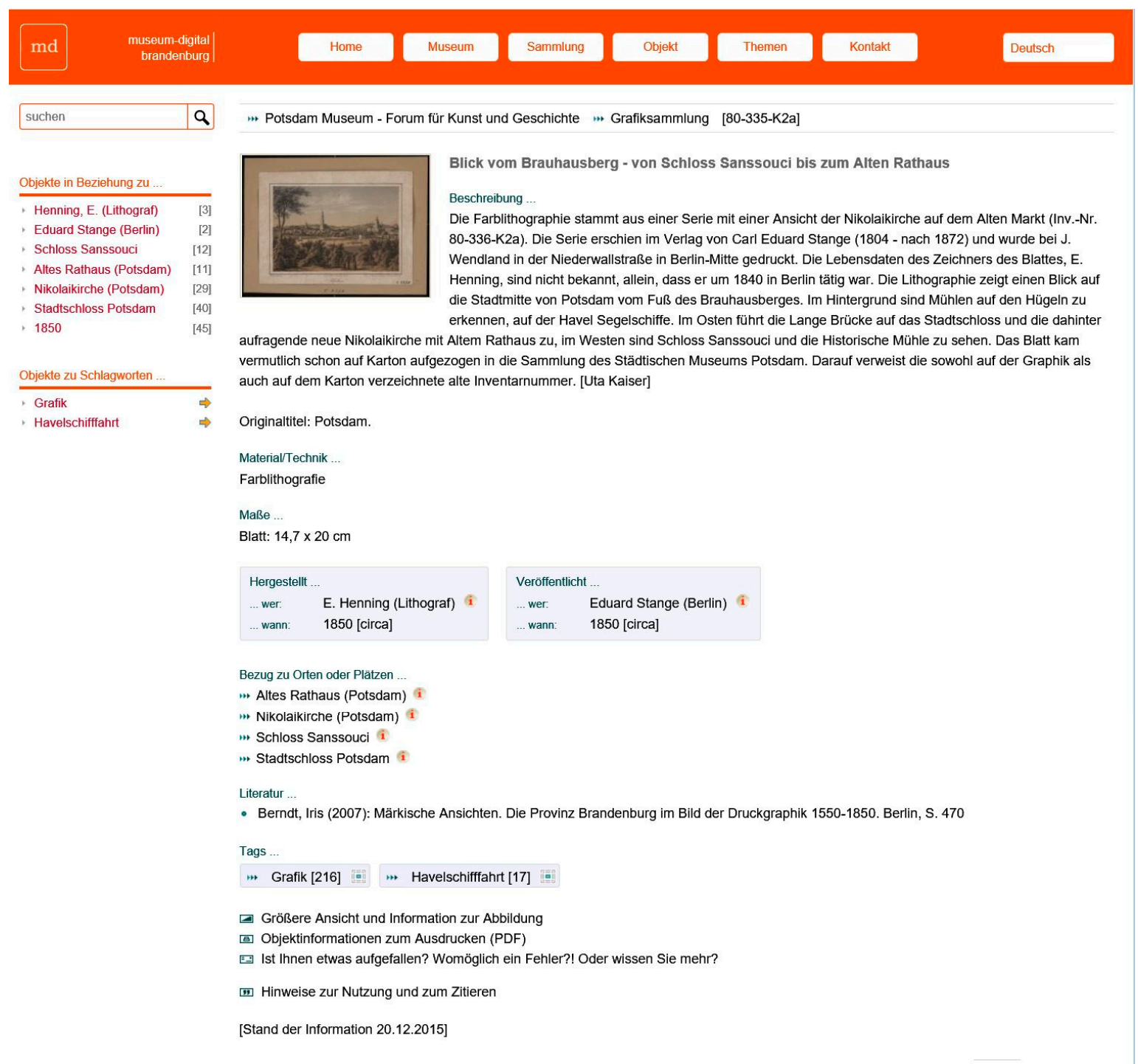

Figure 3. Dataset "Blick vom Brauhausberg - von Schloss Sanssouci bis zum Alten Rathaus" as part of the project "Historical images of Brandenburg" on the platform museum-digital.de [56]. 


\begin{tabular}{|c|c|c|}
\hline 4 & \multicolumn{2}{|c|}{ Anmelden } \\
\hline DEUTSCHE DIGITALE BIBLIOTHEK & Blick vom Brauhausberg & 0 \\
\hline Kultur und Wissen online & $\square$ Nur Objekte mit Digitalisat & Erweiterte Suche \\
\hline
\end{tabular}

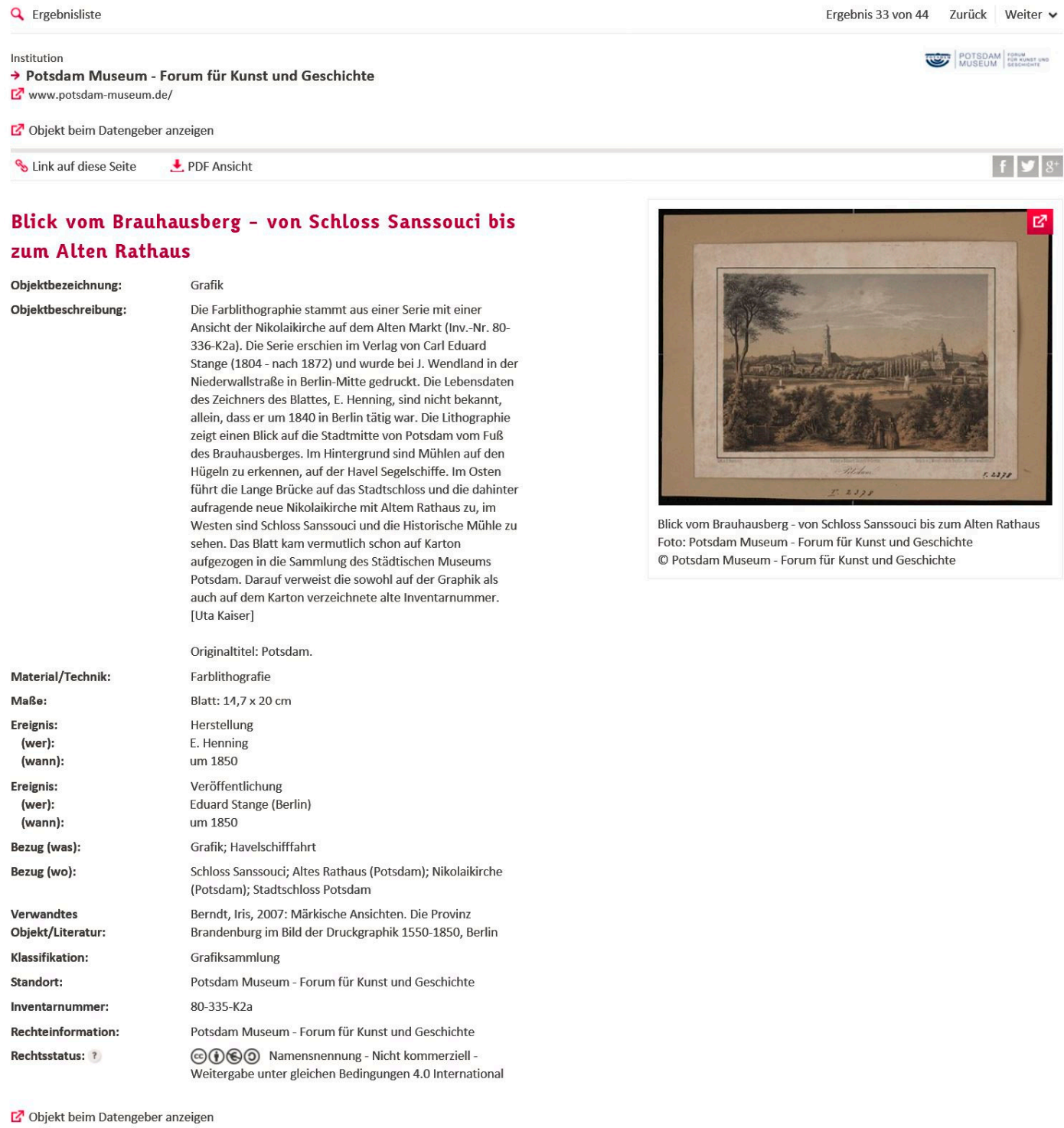

Figure 4. Dataset "Blick vom Brauhausberg-von Schloss Sanssouci bis zum Alten Rathaus" as an example for data exchange from museum-digital to the DDB [57].

The DDB will be the main German participant in the "Europeana." In preparation for that data exchange, the DDB adopted the "Europeana Data Model" (EDM) with some adjustments to fulfill national requirements [58]. As a result, all institutions with contributions to the DDB are technically able to export their data to "Europeana."

Beside the data exchange through the DDB, it is also possible to participate in "Europeana" as an individual institution. For example, Brandenburg is represented in the "Europeana" 280 project with a painting from "dkw. Kunstmuseum Dieselkraftwerk Cottbus" [59]. The coordination office supported the gallery throughout the process. 


\subsection{Digital Preservation}

Without digital preservation there is no digital sustainability. So far, Brandenburg does not have an infrastructure for digital preservation well suited for cooperative use. Therefore, it is a priority for the interdisciplinary task force to address that sustainability gap. At the moment, a concept is under development and will lay the ground for future works. The University of Applied Sciences Potsdam is actively contributing its research on an ongoing basis.

A new potential partner for digital preservation is the Zuse Institute Berlin (ZIB) [60], an interdisciplinary research institute for applied mathematics and data-intensive high-performance computing with adequate IT infrastructure. Currently, the ZIB develops solutions for digital preservation of cultural heritage in Berlin [61], which can be adapted for Brandenburg.

\section{Discussion and Conclusions}

\subsection{Cultural Heritage, Tourism and Civic Participation}

Tourism is an important economic factor for Brandenburg. The Tourism Marketing Brandenburg $\mathrm{GmbH}$ (TMB) operates a website for touristic information about the state of Brandenburg, which includes the display of cultural heritage sites [62] on an interactive map. Many of them belong to the "Palaces and Parks in Potsdam and Berlin" ensemble [63]. It combines places located in the two neighboring states of Berlin and Brandenburg and is one of 37 cultural sites of Germany listed as World Heritage [64]. Although the access to the parks is free of charge, more than 300,000 tourists paid for a guided tour to see the palace named "Sans, Souci" in 2014 [65].

Outside the narrow scope of tourism, the Wikimedia foundation organized several international contests to raise awareness for monuments. Since 2010, more than one million images [66] have been contributed to Wikipedia articles and other related websites. The Wikipedia list of monuments for Brandenburg contains the location of monuments in 419 towns and villages [67], which illustrates the importance and value of cultural heritage for tourism marketing and civic participation. Furthermore, open access digital content can be used for formal or informal education and is a source for scientific research.

\subsection{Strengths and Weaknesses of the Cooperative Approach}

The interdisciplinary task force's concept papers provide a common ground for the planning of digitalization projects. Institutions without adequate IT infrastructure for an online database or digital preservation profit from cooperative solutions. The use of cooperative platforms provides not only space for digital presentation and longer-term stability, but a digital base for data exchange with platforms like DDB and "Europeana." On the other side, institutions that provide cooperative infrastructure profit from the content of all participating institutions, both in volume and regional relevance of the entire collection. Cooperative projects enable digitalization for smaller institutions altogether. Especially central planning and management of these projects by larger institutions or organizations frees smaller institutions from administrative tasks and enabling them to concentrate on the content that is relevant to their particular project. The statewide coordination of projects and the knowledge transfer between them are two additional strong points. The same goes for the IT infrastructures of larger institutions like universities, in contrast to short term project based structures. Finally, the more institutions participate successfully in the initiative of digitalization of cultural heritage in Brandenburg, the more institutions will follow.

Inevitably there are some disadvantages also. One is based on the principle of subsidiarity within the cultural sector: every level of government—federal, state or municipality—is responsible for the development and funding of culture. In the context of digitalization of cultural heritage, this leaves the institutions mainly within the budgetary restraints of the local municipality. In order to apply for additional funding, institutions must declare the value of collections outside the scope of their municipality. That point is in part addressed by thematically based regional or statewide projects. 
The funding of projects and the coordination office is directly connected to this. The projects are not viable without the state's financial commitment or other third-party funds, for example the federal government as main sponsor of the DDB. Brandenburg supported digitalization projects and the coordination office with a total of $€ 150,000$ in 2014, with equal funds for 2015 and 2016. In addition, Brandenburg contributes about $€ 43,000$ to the funding of the DDB annually [68]. These funds can only be addressed within the respective year, without the option of transferring funds to the next. Another disadvantage is the focus on already existing platforms. That concentration leaves some areas unattended, simply due to the lack of adequate platforms. Finally, the cooperation and communication between many institutions is not without challenges either.

\subsection{Prospects for Sustainable Digital Cultural Heritage in Brandenburg}

The government of Brandenburg considers the service of the coordination office to be vital to the digitalization process and is about to elevate its status to a consecutive service, stating that the continued support of the cooperative approach and the coordination office is the most important task of the government regarding digitalization of cultural heritage [69]. The stability of funding for projects will be an ongoing challenge, because most of the cultural sector has an optional and not mandatory status. It is therefore susceptible to financial crises. The Ministry of Science, Research and Culture also supports the task force's conceptual work regarding digital preservation. In cooperation with the research of the University of Applied Sciences Potsdam and in light of options for solutions with regional partners, the basis for digital preservation will be developed within the next years. Sustainability is achieved through long-term commitment of institutions and the determination of individuals. Furthermore, an interdisciplinary approach strengthens the political and public position of the cultural community, in order to secure funding. A collective and collaborative approach to develop solutions for digital preservation is more likely to succeed than hundreds of individual and very limited attempts by the numerous institutions in Brandenburg, especially in the long run.

\subsection{Does This Cooperative Approach Work Everywhere?}

A cooperative approach like described above should work in other contexts because of its generic character. This approach is about making things work and not about certain systems or specifications. It bridges gaps in areas of human resources, expertise and IT infrastructure by cooperative and interdisciplinary thinking and acting. The participating institutions as well as the state can only profit from it. The described solution can be especially valuable to regions with similarly weak infrastructures and a wealth of cultural heritage managed by more than just a few institutions.

By contrast, nations with a more centralized organizational structure do not need to rely heavily on cooperative methods. They rely on top-down instructions and a centrally planned infrastructure. The core principle of cooperation, however, does remains the same: Smaller institutions need reliable infrastructures, adequate human resources and guidelines in order to fulfill the demands of digitalization that come from a central administration or other sources. Also, some nations might not see the benefits of such an interdisciplinary concept of cooperation simply because they can afford single solutions for all their institutions. In the near future that could change, considering the complexity and long-term challenges of digital preservation for example.

The integration of information from different disciplines and institutions into portals like "Europeana" depends on common regulations and cooperative approaches in order to create significant and reliable information sources.

\subsection{Conclusions}

In conclusion, there are rather limited alternatives for digitalization of cultural heritage in Brandenburg. The general idea of an interdisciplinary approach was proven by several successful projects. It relies on the openness and determination of institutions, organizations and individuals. Nevertheless, additional work needs to be done and financial resources need to be secured to sustain 
the digital resources created by these projects. All kinds of digital display contribute to the promotion of cultural heritage and the associated regions, especially for tourism and civic participation. Institutions such as archives, libraries and museums should be able to participate in that digital display in order to add valuable, authentic and genuine information. These institutions are vital to the preservation of tangible cultural heritage and therefore add substance to digitalization. Sustainability of digital resources is directly connected to the preservation of unique original material. Cultural heritage belongs to everyone. It should be actively shared, discussed and used [70]. The more people learn and know about their cultural heritage, the more they will care about it. Digitalization means easier access to cultural heritage, not only locally but globally. This is the only way to achieve and strengthen a broad interest and thereby sustain its future.

Acknowledgments: The coordination office is funded by the Ministry of Science, Research and Culture in Brandenburg. Publications, including open access publishing, on the progress of digitalization of Cultural Heritage in Brandenburg are covered as part of that funding.

Conflicts of Interest: The author declares no conflict of interest. The report represents a summary of the challenges associated with digitalization of cultural heritage and solutions developed by an independent and interdisciplinary task force. The Ministry of Science, Research and Culture in Brandenburg provide financial support to projects and the coordination office, without stipulation of the task force's work or execution of the projects. The founding sponsor had no role in the design of the report; in the collection, analyses, or interpretation of data; in the writing of the manuscript, and in the decision to publish the results.

\section{References}

1. UNESCO Intangible Cultural Heritage. What Is Intangible Cultural Heritage? Available online: http:/ /www.unesco.org/culture/ich/en/what-is-intangible-heritage-00003 (accessed on 30 May 2016).

2. UNESCO German Commission for UNESCO. Intangible Cultural Heritage. Available online: https://www.unesco.de/en/kultur/immaterielles-kulturerbe.html (accessed on 30 May 2016).

3. German National Tourist Board: Incoming-Tourism Germany. Facts and Figures 2014. Available online: https: //www.germany.travel/media/pdf/dzt_marktforschung/GNTB_Incoming-Tourism-Germany-2015.pdf (accessed on 30 May 2016).

4. Statistisches Bundesamt: Pressemitteilung Nr. 098 vom 16.03.2015. Available online: https://www. destatis.de/DE/PresseService/Presse/Pressemitteilungen/2015/03/PD15_098_63931.html (accessed on 30 May 2016).

5. Europeana Foundation: Europeana. Available online: http://www.europeana.eu/portal/ (accessed on 30 May 2016).

6. Stiftung Preußischer Kulturbesitz (Prussian Cultural Heritage Foundation): Deutsche Digitale Bibliothek. Available online: https:/ / www.deutsche-digitale-bibliothek.de/?lang=en (accessed on 30 May 2016).

7. Merriam-Webster, Incorporated: Merriam Webster Dictionary. Available online: http://www.merriamwebster.com (accessed on 30 May 2016).

8. Deutsche Forschungsgemeinschaft (DFG): Scientific Library Services and Information Systems (LIS). Available online: http://www.dfg.de/en/dfg_profile/mission/index.html (accessed on 30 May 2016).

9. Deutsche Forschungsgemeinschaft (DFG): Praxisregeln: Digitalisierung. 2013. Available online: http://www.dfg.de/formulare/12_151/12_151_de.pdf (accessed on 30 May 2016).

10. Joint Steering Committee for Development of RDA: RDA: Resource Description and Access. Available online: http:/ / www.rda-jsc.org/archivedsite/rda.html (accessed on 30 May 2016).

11. Brandenburgisches Landeshauptarchiv: Brandenburgisches Archivportal. Available online: http:/ / www.landeshauptarchiv-brandenburg.de/index.php/landesfachstelle/archivberatung/121-landes fachstelle/archivberatung/262-brandenburgisches-archivportal (accessed on 30 May 2016).

12. Deutsche Bibliotheksverband e.V.: Landesverbände/Brandenburg/Mitglieder. Available online: http: //www.bibliotheksverband.de/landesverbaende/brandenburg/mitglieder.html (accessed on 30 May 2016).

13. Museumsverband des Landes Brandenburg e.V.: Museen. Available online: http://www.museenbrandenburg.de/6.0.html?\&L=3 (accessed on 23 May 2016). 
14. Köstering, S. Museumsentwicklungskonzeption für das Land Brandenburg. Museumsblätter. Mitteilungen des Museumsverbandes Brandenburg. June 2009, pp. 10-55. Available online: http:/ / www.museen-brandenburg. de/fileadmin/bilder/Museumsblaetter/Museumsblaetter_14.pdf (accessed on 30 May 2016).

15. Brandenburgisches Landesamt für Denkmalpflege und Archäologisches Landesmuseum (BLDAM): Denkmale in Brandenburg. Available online: http://ns.gis-bldam-brandenburg.de/hida4web/search? smode=advanced (accessed on 30 May 2016).

16. Ministerium für Wissenschaft, Forschung und Kultur des Landes Brandenburg: Strategiepapier zur Digitalisierung von Kulturgut im Land Brandenburg. 2009. Available online: www.mwfk.brandenburg.de/ media/lbm1.a.1491.de/strategiepapier.pdf (accessed on 30 May 2016).

17. Brokfeld, J.; Duwe, M.; Grimm, F.; Höppe, M.; Lindemann, T.; Preuß, U.; Schmidt, M. Konzept zur Beteiligung von Kultureinrichtungen des Landes Brandenburg an der Deutschen Digitalen Bibliothek $(D D B)$; University of Applied Sciences Potsdam: Potsdam, Germany, 2012. Available online: http:/ /opus4.kobv.de/opus4-fhpotsdam/files/233/Konzept_zur_Beteiligung_von_Kultureinrichtungen_ des_Landes_Brandenburg_an_der_DDB.pdf (accessed on 30 May 2016).

18. Stiftung Preußischer Kulturbesitz (Prussian Cultural Heritage Foundation): Deutsche Digitale Bibliothek: Cooperation Agreement. Available online: https://www.deutsche-digitale-bibliothek.de/content/ueberuns/kooperationsvertrag?lang=en (accessed on 30 May 2016).

19. Fachhochschule Potsdam: Koordinierungsstelle Brandenburg-digital. Available online: www.brandenburgdigital.org (accessed on 30 May 2016).

20. Becher, J.; Michalowsky, U.; Paschke, R.; Preuß, U.; Scholz, M. Die Digitale Präsentation von Kulturgut im Land Brandenburg. Available online: http://nbn-resolving.de/urn/resolver.pl?urn:nbn:de:kobv:525-5433 (accessed on 30 May 2016).

21. Preuss, Ulf: Participation of Small Cultural Heritage Institutions in the Digital World. Available online: https:/ / proceedings.bobcatsss2014.hb.se/article/view/338 (accessed on 30 May 2016).

22. Brandenburgische Gesellschaft für Kultur und Geschichte gemeinnützige GmbH: Startseite. Available online: http:/ / www.hbpg.de/ (accessed on 30 May 2016).

23. Brandenburgisches Landeshauptarchiv: The Brandenburg Main State Archiv. Available online: http:/ /www. landeshauptarchiv-brandenburg.de/index.php/english (accessed on 30 May 2016).

24. Brandenburgisches Landesamt für Denkmalpflege und Archäologisches Landesmuseum. Available online: http:/ / www.bldam-brandenburg.de/ (accessed on 30 May 2016).

25. Brandenburgisches Literaturbüro. Available online: http://www.literaturlandschaft.de/ (accessed on 30 May 2016).

26. University of Applied Sciences Potsdam. Available online: http://www.fh-potsdam.de/ (accessed on 30 May 2016).

27. Filmmuseum Potsdam. Available online: http://www.filmmuseum-potsdam.de/index.php?id= f6cd474b9156155880820001a0a0a5c1\&sessionLanguage=en (accessed on 30 May 2016).

28. German Geological Society (DGGV). Available online: http://www.dggv.de/en/home.html (accessed on 30 May 2016).

29. Library Wissenschaftspark Albert Einstein. Available online: http://bib.telegrafenberg.de/en/librarywissenschaftspark-albert-einstein/ (accessed on 30 May 2016).

30. Film University Babelsberg Konrad Wolf: Library. Available online: http://www.filmuniversitaet.de/en/ universittsbibliothek.html (accessed on 30 May 2016).

31. Museumsverband des Landes Brandenburg e.V. Available online: http://www.museen-brandenburg.de/3. 0.html (accessed on 30 May 2016).

32. Sorbisches Institut-Serbski institut. Available online: http://www.serbski-institut.de/ (accessed on 30 May 2016).

33. Stadt- und Landesbibliothek Potsdam. Available online: http://www.bibliothek.potsdam.de/ (accessed on 30 May 2016).

34. Stiftung Brandenburgische Gedenkstätten. Available online: http://www.stiftung-bg.de/ (accessed on 30 May 2016).

35. Prussian Palaces and Gardens Foundation Berlin-Brandenburg. Available online: http://www.spsg.de/en/ home/ (accessed on 30 May 2016). 
36. Potsdam University Library. Available online: http://info.ub.uni-potsdam.de/?lang=gb\& (accessed on 30 May 2016).

37. Stiftung Europa-Universität Viadrina: University Library. Available online: https:/ /www.ub.europa-uni. de/en/index.html (accessed on 30 May 2016).

38. Centre for Contemporary History Potsdam. Available online: http://www.zzf-pdm.de/site/292/default. aspx (accessed on 30 May 2016).

39. Universität Potsdam/Universitätsbibliothek: Digitales Brandenburg: Geologische Karten. Available online: http://digital.ub.uni-potsdam.de/nav/classification/42482 (accessed on 30 May 2016).

40. Museumsverband des Landes Brandenburg e.V.: Museum-digital/Brandenburg. Available online: www. museum-digital.de/brandenburg/ (accessed on 30 May 2016).

41. Berlin State Library. The Kalliope Union Catalog. Available online: http://kalliope-verbund.info/en/about/ history.html (accessed on 30 May 2016).

42. Weymann, A.; Luna, O.; Rodrigo, A.; Müller, C.; Nickolay, B.; Schneider, J.; Barzik, K. Einführung in die Digitalisierung von Gedrucktem Kulturgut; Ibero-Amerikanisches Institut, Stiftung Preußischer Kulturbesitz: Berlin, Germany, 2010; Available online: http:/ /www.iai.spk-berlin.de/fileadmin/dokumentenbibliothek/ handbuch/Handbuch_Digitalisierung_IAI_IPK_Online_druck.pdf (accessed on 30 May 2016).

43. Weitzmann, J.H.; Klimpel, P. Handreichung Recht, 2014. Available online: http:/ /dx.doi.org/10.12752/2.0. 002.1 (accessed on 30 May 2016).

44. Servicestelle Digitalisierung: digiS-Service Center Digitization Berlin. Available online: http:// www.servicestelle-digitalisierung.de/confluence/pages/viewpage.action?pageId=3571725 (accessed on 30 May 2016).

45. Filmmuseum Potsdam. Available online: http://www.museum-digital.de/brandenburg/index.php?t= institution\&instnr=8 (accessed on 30 May 2016).

46. Museumsverband des Landes Brandenburg e.V.: Brandenburg im Bild. Available online: http://www. museum-digital.de/themator/ausgabe/showthema.php?m_tid=497\&tid=497\&ver=brandenburg (accessed on 30 May 2016).

47. Museumsverband des Landes Brandenburg e.V.: Glasplattennegative. Available online: http://www. museum-digital.de/brandenburg/index.php?t=listen\&type=2\&gestag=11946 (accessed on 30 May 2016).

48. Museumsverband des Landes Brandenburg e.V.: Populäre Schriftzeugnisse. Available online: http://www. museum-digital.de/themator / ausgabe/showthema.php?m_tid=488\&tid=488\&ver=brandenburg (accessed on 30 May 2016).

49. Stadt- und Landesbibliothek Potsdam. BrandenburgDOK. Digitalisierte Heimatkalender. Available online: https://opus4.kobv.de/opus4-slbp/solrsearch/index/search/searchtype/collection/id/18463 (accessed on 30 May 2016).

50. Museumsverband des Landes Brandenburg e.V.: Über die Grenze. Available online: http://www. museum-digital.de/themator / ausgabe/showthema.php?m_tid=458\&tid=458\&ver=brandenburg (accessed on 30 May 2016).

51. International Council of Museums ICOM: What Is LIDO. Available online: http://network.icom.museum/ cidoc/working-groups/lido/what-is-lido/ (accessed on 30 May 2016).

52. Potsdam Museum-Forum für Kunst und Geschichte. Available online: http://www.potsdam-museum.de/ (accessed on 30 May 2016).

53. Deutsche Nationalbibliothek. Integrated Authority File (GND). Available online: http://www.dnb.de/EN/ Standardisierung/GND/gnd_node.html (accessed on 30 May 2016).

54. The Getty Research Institute. Getty Thesaurus of Geographic Names ${ }^{\circledR}$ Online. Available online: http:/ / www.getty.edu/research/tools/vocabularies/tgn/ (accessed on 8 July 2016).

55. Linked Data. Available online: http://linkeddata.org/ (accessed on 30 May 2016).

56. Potsdam Museum-Forum für Kunst und Geschichte. Blick vom Brauhausberg: Von Schloss Sanssouci bis zum Alten Rathaus. Available online: http://www.museum-digital.de/themator/ausgabe/showthema. php?m_tid=497\&tid=497\&ver=brandenburg (accessed on 8 July 2016). 
57. Stiftung Preußischer Kulturbesitz (Prussian Cultural Heritage Foundation). Deutsche Digitale Bibliothek. Blick vom Brauhausberg: Von Schloss Sanssouci bis zum Alten Rathaus. Available online: https://www.deutsche-digitale-bibliothek.de/item/U4AQJMHXMAV4CPBSM5PSP45PKYV36JTA?view Type=list\&thumbnail-filter=on\&query=brauhausberg+schloss\&rows=20\&isThumbnailFiltered=true\&offset =0\&firstHit=PCMXC3ZZELHOOUL356POXWCP3625IIOJ\&lastHit=lasthit\&hitNumber=4 (accessed on 8 July 2016).

58. Stiftung Preußischer Kulturbesitz (Prussian Cultural Heritage Foundation). Deutsche Digitale Bibliothek. Von ESE zu EDM und darüber hinaus: Wie Europeana Zugang zu Objekten des kulturellen Erbes ermöglicht. Available online: https://www.deutsche-digitale-bibliothek.de/content/ueber-uns/aktuelles/von-esezu-edm-und-darueber-hinaus-wie-europeana-zugang-zu-objekten-des-kulturellen-erbes-ermoeglicht (accessed on 8 July 2016).

59. Europeana Collections. Tango bis es weh tut (by Klaus Killisch). Available online: http://www.europeana. eu/portal/record/2063623/GER_280_012.html (accessed on 8 July 2016).

60. Zuse Institute Berlin (ZIB): ZIB. Available online: http://www.zib.de/ (accessed on 30 May 2016).

61. Klindt, M.; Amrhein, K. One Core Preservation System for All your Data. No Exceptions! In Proceedings of the 12th International Conference on Digital Preservation, Chapel Hill, NC, USA, 2-6 November 2015; School of Information and Library Science, University of North Carolina at Chapel Hill: Chapel Hill, NC, USA, 2016; pp. 101-108. Available online: http://phaidra.univie.ac.at/o:429524 (accessed on 30 May 2016).

62. TMB Tourism Marketing Brandenburg GmbH: Brandenburg's Sights. Available online: http://www. brandenburg-tourism.com/discover-brandenburg/sights.html?no_cache=1 (accessed on 30 May 2016).

63. UNESCO World Heritage Centre: World Heritage List-Palaces and Parks of Potsdam and Berlin. Available online: http://whc.unesco.org/en/list/532 (accessed on 30 May 2016).

64. UNESCO/World Heritage Centre: World Heritage List-Germany. Available online: http://whc.unesco. org/en/statesparties/de (accessed on 30 May 2016).

65. Landeshauptstadt Potsdam. Kultur: Besucher kultureller Einrichtungen und Sehenswürdigkeiten in der Landeshauptstadt Potsdam seit 2010. Available online: https://www.potsdam.de/content/kultur-besucherkultureller-einrichtungen-und-sehenswuerdigkeiten-der-landeshauptstadt (accessed on 30 May 2016).

66. Wikimedia Foundation. Wiki Loves Monuments. Available online: http://www.wikilovesmonuments.org/ (accessed on 30 May 2016).

67. Wikimedia Foundation. Baudenkmal in Brandenburg nach Gemeinde. Available online: https://de. wikipedia.org/wiki/Kategorie:Baudenkmal_in_Brandenburg_nach_Gemeinde (accessed on 30 May 2016).

68. Ministerium für Wissenschaft, Forschung und Kultur des Landes Brandenburg. Pressemitteilung vom 22.05.2014-Brandenburgische Kulturgüter Werden Fit Gemacht für das Digitale Zeitalter. Available online: http://www.mwfk.brandenburg.de/cms/detail.php/bb1.c.364876.de (accessed on 30 May 2016).

69. Antwort der Landesregierung auf die Kleine Anfrage 697 der Abgeordneten Anja Heinrich der CDU-Fraktion Drucksache 6/1574. (Drucksache 6/1930), 2105. Parlamentsdokumentation Brandenburg. Available online: https:/ /www.parlamentsdokumentation.brandenburg.de/starweb/LBB/ELVIS/parladoku/w6/ drs/ab_1900/1930.pdf (accessed on 15 July 2016).

70. Statens Museum for Kunst National Gallery of Denmark. Sharing is caring. Openness and Sharing in the Cultural Heritage Sector. Available online: http://www.smk.dk/fileadmin/user_upload/Billeder/ forsiden/94124_sharing_is_Caring_UK.pdf (accessed on 30 May 2016).

(C) 2016 by the author; licensee MDPI, Basel, Switzerland. This article is an open access article distributed under the terms and conditions of the Creative Commons Attribution (CC-BY) license (http://creativecommons.org/licenses/by/4.0/). 